\title{
Dengue Hemorrhagic Fever Virus in Saudi Arabia: A Review
}

Jaffar A. Al-Tawfiq, MD, FACP, FRCP (Edin), FRDP (London) ${ }^{1,2}$ and Ziad A. Memish, MD, FRCPC, FACP, FFPH ${ }^{3,4}$

${ }^{1}$ Johns Hopkins Aramco Healthcare, Dhahran 31311, Kingdom of Saudi Arabia

${ }^{2}$ Indiana University School of Medicine, Indianapolis, IN 46202 (USA)

${ }^{3}$ Ministry of Health, Riyadh 1151, Kingdom of Saudi Arabia

${ }^{4}$ Hubert Department of Global Health, Rollins School of Public Health, Emory University, Atlanta, GA, USA.

\section{Correspondence:}

This is the author's manuscript of the article published in final edited form as:

Al-Tawfiq, J. A., \& Memish, Z. A. (2018). Dengue Hemorrhagic Fever Virus in Saudi Arabia: A Review. VectorBorne and Zoonotic Diseases, 18(2), 75-81. https://doi.org/10.1089/vbz.2017.2209 


\begin{abstract}
:
Dengue fever is a global disease with a spectrum of clinical manifestation ranging from mild febrile disease to a severe disease in the form of dengue hemorrhagic fever and dengue shock syndrome. Dengue virus is one viral hemorrhagic fever that exists in the Kingdom of Saudi Arabia in addition to Alkhumra (Alkhurma) Hemorrhagic Fever, Chikungunya virus, CrimeanCongo Hemorrhagic Fever, and Rift Valley Fever. The disease is limited to the Western and South-western regions of Saudi Arabia where Aedes aegypti exists. The majority of the cases in Saudi Arabia had mild disease and is related to serotypes 1-3 but not 4. The prospect for Dengue virus control relies on vector control, health education and possibly vaccine use. Despite extensive collaborative efforts between multiple governmental sectors including Ministry of Health, Ministry of Municipalities and Rural Affairs, and Ministry of Water dengue remains a major public health concern in the regions affected.
\end{abstract}

\title{
Keywords:
}

Dengue hemorrhagic fever virus; DHFV; 


\section{Introduction:}

Dengue fever (DF) is a global disease with a spectrum of clinical manifestation ranging from mild febrile disease to a severe disease in the form of dengue hemorrhagic fever (DHF) and dengue shock syndrome (DSS). According to the World Health Organization, severe dengue disease in suspected dengue patients is defined as the presence of any of severe plasma leakage that leads to shock (dengue shock) and/or fluid accumulation with respiratory distress; severe bleeding; or severe organ impairment (World Health Organization (WHO) 2012).

Dengue infection occurs in an endemic form in 128 countries worldwide (Khetarpal \& Khanna 2016). DF is one of several viral hemorrhagic fevers that exist in the Kingdom of Saudi Arabia (Alhaeli et al. 2016) in addition to Alkhumra (Alkhurma) Hemorrhagic Fever (AHF) (Zaki 1997; Al-Tawfiq \& Memish 2017), Chikungunya Haemorrhagic Fever (Hussain et al. 2013), CrimeanCongo Hemorrhagic Fever (CCHF) (Leblebicioglu et al. 2015; El-Azazy \& Scrimgeour 1997; Hassanein et al. 1997), and Rift Valley Fever (RVF) (Balkhy \& Memish 2003; Al-Afaleq \& Hussein 2011). Of the four serotypes of Dengue virus, serotypes 1-3 but not 4 were reported in Saudi Arabia (Ashshi 2017). The first description of Dengue fever in Saudi Arabia dates back to 1994 when Dengue virus serotype 2 (DEN-2) was isolated from a fatal and a non-fatal cases in Jeddah, Saudi Arabia (Fakeeh \& Zaki 2001).

\section{Search strategy}

The search included MEDLINE and Scopus databases for articles published in English as follows:

\#1: "Dengue" OR “Dengue Virus" OR “Dengue Hemorrhagic Fever" OR "Dengue Fever" 
\#2: "Saudi Arabia" OR "Kingdom of Saudi Arabia";

\#3: \#1 AND \#2.

In addition, we searched the Saudi Epidemiology Bulletin (available from the Saudi Ministry of Health at: http://www.fetp.edu.sa/Bulletin.html ).

\section{The Virus:}

Dengue fever, DHF, and DSS are caused by the dengue viruses (DENV). Dengue virus is a member of the genus Flavivirus, a member of the family Flaviviridae. The genus Flavivirus is classified into two broad categories based on the vector of transmission: tick-borne viruses and mosquito-borne viruses (figure 1). The Dengue virus is a mosquito-borne virus. Four antigenically related but distinct dengue virus serotypes exist and are: dengue virus types 1-4 (DENV-1, DENV-2, DENV-3, and DENV-4) (Khetarpal \& Khanna 2016).

\section{Virus Transmission:}

The Dengue viruses are transmitted to humans by the females of the mosquito Aedes. The most important vector is A. aegypti and other species such as A. albopictus, A. polynesiensis, and A. niveushave are secondary vectors (Malavige et al. 2004). The virus is limited to the Western and South-western regions of Saudi Arabia (Fakeeh \& Zaki 2001; El-Kafrawy et al. 2016; Ayyub et al. 2006; Khan et al. 2008; Al-Azraqi et al. 2013; Alhaeli et al. 2016). Four different Aedes species were identified in the Western part of Saudi Arabia (Alikhan et al. 2014; Abdullah \& Merdan 1995; Jupp et al. 2002; Al Ahmad et al. 2011; Alahmed et al. 2009; Kheir et al. 2010; Aziz et al. 2012) and only A. caspius was identified in the Eastern Saudi Arabia (Wills et al. 1985) (table 1). In a case control study, the following factors were associated with the risk of 
Dengue virus infection: presence of stagnant water $(\mathrm{OR}=4.9)$, indoor larvae $(\mathrm{OR}=2.2)$, construction sites ( $\mathrm{OR}=2.2)$, and older age $(\mathrm{OR}=1.2)$ (Kholedi et al. 2012). It is known that rain fall in Jeddah is low. The occurrence of $A$. aegypti with Dengue fever in Jeddah is in paradox with the low level of rain; however, water containers play a role as breeding sites for $A$. aegypti (Ghaznawi et al. 1997; El-Gilany et al. 2010). In addition, the occurrence of huge constructions between 2008 and 2012 in Makkah, Saudi Arabia may had resulted in increased number of cases due to the formation of stagnant water (alwafi et al. 2013). Moreover, Jeddah is the Hajj entry point and is the largest commercial port and airport welcoming many Pilgrims coming from Dengue High Disease Burden. Thus in this context, the role of International Travel as the source of Dengue is a possibility. A recent study showed the role of visitors from dengue endemic countries in the importation of the virus into Saudi Arabia (Al-Saeed et al. 2017). The study showed that all dengue viruses in 2010-2015 were from the circulating Indian subcontinent lineage of the Cosmopolitan genotype (Al-Saeed et al. 2017).

\section{Incidence:}

In Saudi Arabia, Dengue fever registry was made electronically in 2008 and Dengue is a notifiable disease in Saudi Arabia. The incidence of DENV infection among tested patients varies based on the location, year of the study and the method of testing (table 2) (Ashshi 2017; Ashshi et al. 2017; Fakeeh \& Zaki 2001; Khan et al. 2008; Al-Azraqi et al. 2013; Ayyub et al. 2006; Organji et al. 2017; Shahin et al. 2009; Fakeeh \& Zaki 2003; El-Gilany et al. 2010; alwafi et al. 2013; Gamil et al. 2014; Memish et al. 2011). The number of DENV infection was 6512 cases in 2013; 2081 cases in 2014; 4312 cases in 2015. The number of cases varies between 425 and 4312 per year (Alshamrani et al. n.d.; Organji et al. 2017). The annual number of cases of Dengue virus $\mathrm{n}$ in Saudi Arabia is shown in figure 2 and the highest number of cases was in 
2013, 2015, and 2016. However, the overall prevalence of DENV is $40-48.7 \%$ among clinically suspected patients (Khan et al. 2008; Ayyub et al. 2006) and 31.7\% among random sample of patients attending the outpatients' clinics (Al-Azraqi et al. 2013). In a study from 2008 to 2012, the incidence rate doubled to 110 per 100,000 population in 2009 indicating the occurrence of an outbreak (alwafi et al. 2013). The majority of affected patients are adults and infected children constituted 24\% (Shahin et al. 2009) in one study and 6\% in another study (Ayyub et al. 2006). In a recent study, the age-standardised incidence rates of dengue was 10-99 per 100000 personyears in 2013 (Stanaway et al. 2016).

\section{Seasonality}

In a study of 159 cases in Makkah, $77 \%$ of the cases were during the spring and early summer (Shahin et al. 2009). And another study showed increased cases in the summer months and during the months of December and January (Kholedi et al. 2012). In a study of 4187 cases, the peak cases occurred in April-May (alwafi et al. 2013) and a similar finding was in a report of 264 cases from Jazan (Gamil et al. 2014) and a study of cases in 2013-2014 (Aziz, Salman Abdo AlShami, et al. 2014). Thus, the majority of cases occurred in April-May.

\section{Clinical Presentations:}

Dengue fever is characterized by constitutional findings of fever, severe headache, backache, joint pains, nausea and vomiting, eye pain and rash. The disease affects all age groups but tends to cause milder disease in young children. Dengue virus may cause one of four syndromes/diseases: undifferentiated fever, classic dengue fever, dengue hemorrhagic fever, or dengue shock syndrome. The first 207 patients had mild Dengue fever and only one patient had dengue shock syndrome (DSS) and one had Dengue Hemorrhagic fever (DHF) (Fakeeh \& Zaki 
2001). The affected patients in Saudi Arabia were more likely to be male and of young age group (summarized in table 3). The signs of symptoms of Saudi patients with dengue infections are summarized in table 4 (Ayyub et al. 2006; Khan et al. 2008; El-Gilany et al. 2010; Shahin et al. 2009; Ahmed 2010; Badreddine et al. 2017). The majority of patients (60-93\%) presented with dengue fever, 5-39.4\% had DHF, and about $1 \%$ had DSS. The reported mortality was also low. Dengue infection accounts for a total of $0.15-0.29$ mortality per million person-years in Saudi Arabia in 2013 (Stanaway et al. 2016). Men are more affected than women in the various included studies. This is mainly related to the fact that men work outdoors and that women in Saudi wear clothing covering head to toes (alwafi et al. 2013).

\section{Geographic Distribution}

Dengue virus was mainly reported from the Western and South-western regions of Saudi Arabia (Fakeeh \& Zaki 2001; El-Kafrawy et al. 2016; Ayyub et al. 2006; Khan et al. 2008; Al-Azraqi et al. 2013; Alhaeli et al. 2016). This geographic restriction is directly related to the presence of $A$. aegypti in the region (Alikhan et al. 2014; Jupp et al. 2002; Al Ahmad et al. 2011; Alahmed et al. 2009; Kheir et al. 2010; Aziz et al. 2012) and not in other parts of the Kingdom of Saudi Arabia (Wills et al. 1985; Abdullah \& Merdan 1995). Mathematical modelling showed that central Jeddah districts were the hotspots and the pattern changes greatly with time (Khormi et al. 2011). Using modelling techniques, a total of 111 districts in Jeddah were investigated for the risk of Dengue fever (Khormi \& Kumar 2012). Of those districts, $15 \%$ were high risk, $22 \%$ were medium risk, $16 \%$ were low risk and $46 \%$ were very low risk (Khormi \& Kumar 2012). An analysis of 2288 cases of Dengue fever, the disease was found to be concentrated in the south and central-north regions of Jeddah, Saudi Arabia (Alzahrani et al. 2013). 


\section{Virus Serotypes:}

Dengue virus serotype is associated with the risk of DHF with highest risks with DENV-2, DENV-3, DENV-4 and DENV-1, as well as the pre-existence of anti-dengue antibodies. In the initial study of 985 suspected cases, DEN-2 accounted for 138 (66.7\%) of 207 isolates, DEN-1 for 56 (27\%), and DEN-3 for 13 (6.3\%) (Fakeeh \& Zaki 2001). The contribution of each serotype to Dengue in Saudi Arabia is shown in table 3. However, DENV-4 was not reported in any of the studies based on serology and molecular testing (Fakeeh \& Zaki 2001; Ayyub et al. 2006; Khan et al. 2008; Organji et al. 2017; Fakeeh \& Zaki 2003). Phylogenetic analysis of 19 isolates showed that DENV-1 and DENV-2 caused the 1994 outbreaks and it was an AmericaAfrica genotype (lineage India-2) (Zaki et al. 2008). DENV-3 was isolated in 1997 and the outbreak in 2005-2006 was caused by a strain from genotype Asia (lineage Asia-2) (Zaki et al. 2008). Sequencing of the Dengue virus DENV-1-Jeddah-1-2011 strain showed high similarity with the Asian genotype (D1/H/IMTSSA/98/606 isolate) reported from Djibouti in 1998 (Azhar et al. 2015).

\section{Seroprevalence among asymptomatic individuals:}

The seroprevalence of Dengue virus antibodies among asymptomatic individuals was found to be $47.8 \%$ (927/1939) and among blood donors was 37\% (68/184) (Jamjoom et al. 2016). The seroprevalence of anti-dengue IgG was $31.7 \%$ among asymptomatic persons attending outpatient clinics (Al-Azraqi et al. 2013). In one study, male gender, older age and communal and multi-

story housing were significant factors for positive ELISA tests (Jamjoom et al. 2016). In a seroprevalence study of 1024 soldiers, only $0.1 \%$ tested positive for DENV by ELISA (Memish et al. 2011). Thus, there is variable seroprevalence of dengue among the different population 
studied and is higher among patients attending outpatient clinics (31.7\%) than the general population $(0.1 \%)$. The general population may also represent the different regions of the country which may not be dengue fever areas.

\section{Prospect for Control:}

Strategies to control Dengue virus requires the control of the vector, A. aegypti, through elimination of breeding sites and the elimination of the vector itself. It is important to intensify the use of insecticides to control mosquito due to the quick and efficient knock-down activity (Aziz, Salman Abdo Al-Shami, et al. 2014). In one study in Jazan, Saudi Arabia, A. aegypti mosquitoes were susceptible to Cyfluthrin and had variable resistances to other insecticides such as: ambda-cyhalothrin, Deltamethrin, Permethrin, Fenitrothion, Bendiocarb and DDT (Alsheikh et al. 2016). Health education and awareness of the disease and its vector play a major role in the control of Dengue in Saudi Arabia (Aziz, Salman A Al-Shami, et al. 2014). In one study from Saudi Arabia, high students' knowledge score was associated with family history of Dengue fever, having literate mothers, and age $\geq 17$ years (Ibrahim et al. 2009). Gambusia holbrooki fish was effective in domestic water containers to control A. aegypti (Gamal 2012). In addition, the World Health Organization provides 36 boxes for the control of Dengue fever and includes Aedes control methods, Global Strategy for prevention and control of DF/DHF, and lessons learned from sustained efforts in countries combating dengue virus (Parks \& Lloyd 2004). One dengue virus vaccine was licensed in Latin America and Southeast Asia. Two large phase III randomized controlled trials of this vaccine showed about $60 \%$ against virologically confirmed dengue in the first 13 months post-vaccine (Villar et al. 2015; Capeding et al. 2014). In a metaanalysis of nine studies, the vaccine efficacy was $54 \%$ with reduced efficacy of $34 \%$ for DENV2 (Malisheni et al. 2017). However, the vaccine was associated with higher relative risk of dengue 
infection during the third year post-vaccination (Hadinegoro et al. 2015). The World Health Organization does not recommend the use of the vaccine for widespread vaccination nor for the use in areas with less than 50\% seroprevalence (Anon 2016; World Health Organization 2017).

\section{Conclusion:}

Dengue fever in Saudi Arabia is limited to the Western and South-western regions of the country and is linked to Aedes aegypti. The majority of the patients had mild disease and were caused by serotypes 1-3. Despite extensive collaborative efforts between multiple governmental sectors

including Ministry of Health, Ministry of Municipalities and Rural Affairs, and Ministry of Water, dengue remains a major public health concern in the regions affected. The prospect for Dengue virus control relies on vector control, health education and possibly vaccine use.

\section{References:}

Abdullah, M.A. \& Merdan, A.I., 1995. Distribution and ecology of the mosquito fauna in the southwestern Saudi Arabia. Journal of the Egyptian Society of Parasitology, 25(3), pp.81537. Available at: http://www.ncbi.nlm.nih.gov/pubmed/8586876 [Accessed September 3, 2017].

Al Ahmad, A.M. et al., 2011. Checklist and pictorial key to fourth-instar larvae of mosquitoes (Diptera: Culicidae) of Saudi Arabia. Journal of medical entomology, 48(4), pp.717-37. Available at: http://www.ncbi.nlm.nih.gov/pubmed/21845930 [Accessed September 3, 
2017].

Ahmed, M.M., 2010. Clinical profile of dengue fever infection in King Abdul Aziz University Hospital Saudi Arabia. Journal of infection in developing countries, 4(8), pp.503-10. Available at: http://www.ncbi.nlm.nih.gov/pubmed/20818102 [Accessed September 4, 2017].

Al-Afaleq, A.I. \& Hussein, M.F., 2011. The status of Rift Valley fever in animals in Saudi Arabia: a mini review. Vector borne and zoonotic diseases (Larchmont, N.Y.), 11(12), pp.1513-20. Available at: http://www.liebertonline.com/doi/abs/10.1089/vbz.2010.0245 [Accessed December 30, 2016].

Al-Azraqi, T.A., El Mekki, A.A. \& Mahfouz, A.A., 2013. Seroprevalence of dengue virus infection in Aseer and Jizan regions, Southwestern Saudi Arabia. Transactions of The Royal Society of Tropical Medicine and Hygiene, 107(6), pp.368-371. Available at: http://www.ncbi.nlm.nih.gov/pubmed/23474472 [Accessed September 2, 2017].

Al-Saeed, M.S. et al., 2017. Phylogenetic characterization of circulating Dengue and Alkhumra Hemorrhagic Fever viruses in western Saudi Arabia and lack of evidence of Zika virus in the region: A retrospective study, 2010-2015. Journal of medical virology, 89(8), pp.13391346. Available at: http://doi.wiley.com/10.1002/jmv.24785 [Accessed September 1, 2017].

Al-Tawfiq, J.A. \& Memish, Z.A., 2017. Alkhurma hemorrhagic fever virus. Microbes and infection, 19(6), pp.305-310. Available at: http://linkinghub.elsevier.com/retrieve/pii/S1286457917300655 [Accessed September 1, 2017]. 
Alahmed, A.M. et al., 2009. Mosquito fauna (Diptera: Culicidae) and seasonal activity in Makka Al Mukarramah Region, Saudi Arabia. Journal of the Egyptian Society of Parasitology, 39(3), pp.991-1013. Available at: http://www.ncbi.nlm.nih.gov/pubmed/20120761 [Accessed September 3, 2017].

Alhaeli, A. et al., 2016. The epidemiology of Dengue fever in Saudi Arabia: A systematic review. Journal of Infection and Public Health, 9(2), pp.117-124. Available at: http://www.ncbi.nlm.nih.gov/pubmed/26106040 [Accessed September 2, 2017].

Alikhan, M. et al., 2014. Aedes mosquito species in western Saudi Arabia. Journal of insect science (Online), 14(1), p.69. Available at: https://academic.oup.com/jinsectscience/articlelookup/doi/10.1093/jis/14.1.69 [Accessed September 1, 2017].

Alshamrani, S. et al., Distribution and Determinants of Dengue Fever, Cities of Jeddah and Makkah, Kingdom of Saudi Arabia, 2007 - 2013. Available at: http://kingabdullahfellowship.com/wp-content/uploads/Sultan-Alshamrani-Poster.pdf [Accessed September 2, 2017].

Alsheikh, A.A. et al., 2016. Studies on Aedes aegypti resistance to some insecticides in the Jazan district, Saudi Arabia. Journal of the Egyptian Society of Parasitology, 46(1), pp.209-16. Available at: http://www.ncbi.nlm.nih.gov/pubmed/27363057 [Accessed September 3, $2017]$.

alwafi, O.M. et al., 2013. Dengue Fever in Makkah, Kingdom of Saudi Arabia. American Journal of Research Communication, 1(111), pp.123-139. Available at: http://www.usajournals.com/wp-content/uploads/2013/10/alwafi_Vol111.pdf [Accessed September 3, 2017]. 
Alzahrani, A.G. et al., 2013. Geographical distribution and spatio-temporal patterns of dengue cases in Jeddah Governorate from 2006-2008. Transactions of the Royal Society of Tropical Medicine and Hygiene, 107(1), pp.23-29. Available at:

http://www.ncbi.nlm.nih.gov/pubmed/23222946 [Accessed September 4, 2017].

Anon, 2016. Dengue vaccine: WHO position paper - July 2016. Releve epidemiologique hebdomadaire, 91(30), pp.349-64. Available at: http://www.ncbi.nlm.nih.gov/pubmed/27476189 [Accessed November 11, 2017].

Ashshi, A.M. et al., 2017. Seroprevalence of Asymptomatic Dengue Virus Infection and Its Antibodies Among Healthy/Eligible Saudi Blood Donors: Findings From Holy Makkah City. Virology : research and treatment, 8(0), pp.1-5. Available at: http://insights.sagepub.com/seroprevalence-of-asymptomatic-dengue-virus-infection-andits-antibodi-article-a6172 [Accessed September 1, 2017].

Ashshi, A.M., 2017. The prevalence of dengue virus serotypes in asymptomatic blood donors reveals the emergence of serotype 4 in Saudi Arabia. Virology journal, 14(1), p.107. Available at: http://virologyj.biomedcentral.com/articles/10.1186/s12985-017-0768-7 [Accessed September 1, 2017].

Ayyub, M. et al., 2006. Characteristics of dengue fever in a large public hospital, Jeddah, Saudi Arabia. Journal of Ayub Medical College, Abbottabad: JAMC, 18(2), pp.9-13. Available at: http://www.ncbi.nlm.nih.gov/pubmed/16977805 [Accessed September 2, 2017].

Azhar, E.I. et al., 2015. Complete genome sequencing and phylogenetic analysis of dengue type 1 virus isolated from Jeddah, Saudi Arabia. Virology journal, 12(1), p.1. Available at: http://www.virologyj.com/content/12/1/1 [Accessed September 1, 2017]. 
Aziz, A.T., Al-Shami, S.A., et al., 2014. An update on the incidence of dengue gaining strength in Saudi Arabia and current control approaches for its vector mosquito. Parasites \& vectors, 7(1), p.258. Available at:

http://parasitesandvectors.biomedcentral.com/articles/10.1186/1756-3305-7-258 [Accessed September 1, 2017].

Aziz, A.T. et al., 2012. Household survey of container-breeding mosquitoes and climatic factors influencing the prevalence of Aedes aegypti (Diptera: Culicidae) in Makkah City, Saudi Arabia. Asian Pacific journal of tropical biomedicine, 2(11), pp.849-57. Available at: http://linkinghub.elsevier.com/retrieve/pii/S2221169112602421 [Accessed September 1, 2017].

Aziz, A.T., Al-Shami, S.A., et al., 2014. Promoting health education and public awareness about dengue and its mosquito vector in Saudi Arabia. Parasites \& vectors, 7(1), p.487. Available at: http://parasitesandvectors.biomedcentral.com/articles/10.1186/s13071-014-0487-5 [Accessed September 1, 2017].

Badreddine, S. et al., 2017. Dengue fever. Clinical features of 567 consecutive patients admitted to a tertiary care center in Saudi Arabia. Saudi Medical Journal, 38(10), pp.1025-1033. Available at: http://www.ncbi.nlm.nih.gov/pubmed/28917067 [Accessed November 5, 2017].

Balkhy, H.H. \& Memish, Z.A., 2003. Rift Valley fever: an uninvited zoonosis in the Arabian peninsula. International journal of antimicrobial agents, 21(2), pp.153-7. Available at: http://www.ncbi.nlm.nih.gov/pubmed/12615379 [Accessed December 30, 2016].

Capeding, M.R. et al., 2014. Clinical efficacy and safety of a novel tetravalent dengue vaccine in 
healthy children in Asia: a phase 3, randomised, observer-masked, placebo-controlled trial. Lancet (London, England), 384(9951), pp.1358-65. Available at:

http://linkinghub.elsevier.com/retrieve/pii/S0140673614610606 [Accessed November 11, 2017].

El-Azazy, O.M. \& Scrimgeour, E.M., 1997. Crimean-Congo haemorrhagic fever virus infection in the western province of Saudi Arabia. Transactions of the Royal Society of Tropical Medicine and Hygiene, 91(3), pp.275-8. Available at: http://www.ncbi.nlm.nih.gov/pubmed/9231193 [Accessed December 30, 2016].

El-Gilany, A.-H., Eldeib, A. \& Hammad, S., 2010. Clinico-epidemiological features of dengue fever in Saudi Arabia Dengue fever (DF) Dengue haemorrhagic fever (DHF) Epidemiology Mosquitoes. Asian Pacific Journal of Tropical Medicine, pp.220-223. Available at: http://ac.els-cdn.com/S1995764510600132/1-s2.0-S1995764510600132main.pdf?_tid=b33e9fe0-905f-11e7-a8ea00000aacb360\&acdnat=1504412816_18d01ac4f6516eaec5ac374c3636594f [Accessed September 3, 2017].

El-Kafrawy, S.A. et al., 2016. Multiple Introductions of Dengue 2 Virus Strains into Saudi Arabia from 1992 to 2014. Vector borne and zoonotic diseases (Larchmont, N.Y.), 16(6), pp.391-9. Available at: http://online.liebertpub.com/doi/10.1089/vbz.2015.1911 [Accessed September 1, 2017].

Fakeeh, M. \& Zaki, A.M., 2003. Dengue in Jeddah, Saudi Arabia, 1994-2002. Dengue Bulletin, 27(27), pp.13-18. Available at: http://apps.who.int/iris/bitstream/10665/163900/1/dbv27p13.pdf [Accessed September 3, 
2017].

Fakeeh, M. \& Zaki, A.M., 2001. Virologic and serologic surveillance for dengue fever in Jeddah, Saudi Arabia, 1994-1999. The American journal of tropical medicine and hygiene, 65(6), pp.764-7. Available at: http://www.ncbi.nlm.nih.gov/pubmed/11791972 [Accessed September 1, 2017].

Gamal, Z.A., 2012. Effectiveness of Gambusia holbrooki fish in domestic water containers and controlling Aedes aegypti larvae (Linnaeus, 1762) in southwest Saudi Arabia (Jeddah). Journal of the Egyptian Society of Parasitology, 42(1), pp.1-10. Available at: http://www.ncbi.nlm.nih.gov/pubmed/22662590 [Accessed September 3, 2017].

Gamil, M.A. et al., 2014. Prevalence of Dengue Fever in Jizan Area, Saudi Arabia. Journal of pure and applied microbiology, 8(1), pp.225-231. Available at:

file:///C:/Users/Jaffar/Downloads/Dengue.pdf [Accessed September 3, 2017].

Ghaznawi, H.I. et al., 1997. Surveillance for dengue fever in Jeddah. Eastern Mediterranean Health Journal, 3, pp.567-70. Available at:

http://applications.emro.who.int/emhj/0303/emhj_1997_3_3_567_570.pdf [Accessed September 3, 2017].

Hadinegoro, S.R. et al., 2015. Efficacy and Long-Term Safety of a Dengue Vaccine in Regions of Endemic Disease. New England Journal of Medicine, 373(13), pp.1195-1206. Available at: http://www.ncbi.nlm.nih.gov/pubmed/26214039 [Accessed November 11, 2017].

Hassanein, K.M., El-Azazy, O.M. \& Yousef, H.M., 1997. Detection of Crimean-Congo haemorrhagic fever virus antibodies in humans and imported livestock in Saudi Arabia. 
Transactions of the Royal Society of Tropical Medicine and Hygiene, 91(5), pp.536-7. Available at: http://www.ncbi.nlm.nih.gov/pubmed/9463660 [Accessed December 30, 2016].

Hussain, R., Alomar, I. \& Memish, Z.A., 2013. Chikungunya virus: emergence of an arthritic arbovirus in Jeddah, Saudi Arabia. Eastern Mediterranean Health Journal, 19(5), pp.506-8. Available at: http://www.ncbi.nlm.nih.gov/pubmed/24617133 [Accessed September 7, 2017].

Ibrahim, N.K.R. et al., 2009. Knowledge, attitudes, and practices relating to Dengue fever among females in Jeddah high schools. Journal of Infection and Public Health, 2(1), pp.30-40. Available at: http://www.ncbi.nlm.nih.gov/pubmed/20701858 [Accessed September 4, 2017].

Jamjoom, G.A. et al., 2016. Seroepidemiology of Asymptomatic Dengue Virus Infection in Jeddah, Saudi Arabia. Virology : research and treatment, 7, pp.1-7. Available at: http://www.la-press.com/seroepidemiology-of-asymptomatic-dengue-virus-infection-injeddah-saud-article-a5400 [Accessed September 1, 2017].

Jupp, P.G. et al., 2002. The 2000 epidemic of Rift Valley fever in Saudi Arabia: mosquito vector studies. Medical and veterinary entomology, 16(3), pp.245-52. Available at: http://www.ncbi.nlm.nih.gov/pubmed/12243225 [Accessed September 3, 2017].

Khan, N.A. et al., 2008. Clinical profile and outcome of hospitalized patients during first outbreak of dengue in Makkah, Saudi Arabia. Acta Tropica, 105(1), pp.39-44. Available at: http://www.ncbi.nlm.nih.gov/pubmed/17983609 [Accessed September 2, 2017]. 
Kheir, S.M. et al., 2010. Distribution and seasonal activity of mosquitoes in al Madinah Al Munwwrah, Saudi Arabia. Journal of the Egyptian Society of Parasitology, 40(1), pp.21527. Available at: http://www.ncbi.nlm.nih.gov/pubmed/20503600 [Accessed September 3, 2017].

Khetarpal, N. \& Khanna, I., 2016. Dengue Fever: Causes, Complications, and Vaccine Strategies. Journal of Immunology Research, 2016, pp.1-14. Available at: http://www.ncbi.nlm.nih.gov/pubmed/27525287 [Accessed September 2, 2017].

Kholedi, A.A.N. et al., 2012. Factors associated with the spread of dengue fever in Jeddah Governorate, Saudi Arabia. Eastern Mediterranean health journal = La revue de sante de la Mediterranee orientale = al-Majallah al-sihhiyah li-sharq al-mutawassit, 18(1), pp.1523. Available at: http://www.ncbi.nlm.nih.gov/pubmed/22360006 [Accessed September 2, 2017].

Khormi, H.M. \& Kumar, L., 2012. Assessing the risk for dengue fever based on socioeconomic and environmental variables in a geographical information system environment. Geospatial health, 6(2), p.171. Available at: http://www.ncbi.nlm.nih.gov/pubmed/22639119 [Accessed September 4, 2017].

Khormi, H.M., Kumar, L. \& Elzahrany, R.A., 2011. Modeling spatio-temporal risk changes in the incidence of dengue fever in Saudi Arabia: a geographical information system case study. Geospatial health, 6(1), p.77. Available at: http://www.ncbi.nlm.nih.gov/pubmed/22109865 [Accessed September 3, 2017].

Leblebicioglu, H. et al., 2015. Consensus report: Preventive measures for Crimean-Congo Hemorrhagic Fever during Eid-al-Adha festival. International journal of infectious 
diseases : IJID : official publication of the International Society for Infectious Diseases, 38, pp.9-15. Available at: http://linkinghub.elsevier.com/retrieve/pii/S1201971215001678 [Accessed December 30, 2016].

Malavige, G.N. et al., 2004. Dengue viral infections. Postgraduate Medical Journal, 80(948), pp.588-601. Available at: http://www.ncbi.nlm.nih.gov/pubmed/15466994 [Accessed September 2, 2017].

Malisheni, M. et al., 2017. Clinical Efficacy, Safety, and Immunogenicity of a Live Attenuated Tetravalent Dengue Vaccine (CYD-TDV) in Children: A Systematic Review with Metaanalysis. Frontiers in Immunology, 8, p.863. Available at: http://www.ncbi.nlm.nih.gov/pubmed/28824613 [Accessed November 11, 2017].

Memish, Z.A. et al., 2011. Seroprevalence of Alkhurma and other hemorrhagic fever viruses, Saudi Arabia. Emerging infectious diseases, 17(12), pp.2316-8. Available at: http://www.ncbi.nlm.nih.gov/pubmed/22172587 [Accessed November 30, 2016].

Moher, D. et al., 2009. Preferred reporting items for systematic reviews and meta-analyses: the PRISMA Statement. Open medicine : a peer-reviewed, independent, open-access journal, 3(3), pp.e123-30. Available at: http://www.ncbi.nlm.nih.gov/pubmed/21603045 [Accessed December 9, 2016].

Organji, S.R., Abulreesh, H.H. \& Osman, G.E.H., 2017. Circulation of Dengue Virus Serotypes in the City of Makkah, Saudi Arabia, as Determined by Reverse Transcription Polymerase Chain Reaction. The Canadian journal of infectious diseases \& medical microbiology $=$ Journal canadien des maladies infectieuses et de la microbiologie medicale, 2017, p.1646701. Available at: https://www.hindawi.com/journals/cjidmm/2017/1646701/ 
[Accessed September 1, 2017].

Parks, W. \& Lloyd, L., 2004. Planning social mobilization and communication for dengue fever prevention and control. A Step-by-Step Guide. Available at: http://www.who.int/immunization/hpv/communicate/planning_social_mobilization_and_co mmunication_for_dengue_fever_prevention_and_control_who_cds_wmc_2004.pdf [Accessed November 10, 2017].

Saudi Ministry of Health, Statistical Yearbook. Available at: http://www.moh.gov.sa/en/Ministry/Statistics/book/Pages/default.aspx [Accessed September 4, 2017].

Shahin, W. et al., 2009. Dengue fever in a tertiary hospital in Makkah, Saudi Arabia. Dengue Bulletin, 33. Available at: http://apps.who.int/iris/bitstream/10665/170727/1/db2009v33p34.pdf [Accessed September $2,2017]$.

Stanaway, J.D. et al., 2016. The global burden of dengue: an analysis from the Global Burden of Disease Study 2013. The Lancet. Infectious diseases, 16(6), pp.712-723. Available at: http://linkinghub.elsevier.com/retrieve/pii/S1473309916000268 [Accessed September 1, 2017].

Villar, L. et al., 2015. Efficacy of a Tetravalent Dengue Vaccine in Children in Latin America. New England Journal of Medicine, 372(2), pp.113-123. Available at: http://www.ncbi.nlm.nih.gov/pubmed/25365753 [Accessed November 11, 2017].

Wills, W.M. et al., 1985. Sindbis virus isolations from Saudi Arabian mosquitoes. Transactions 
of the Royal Society of Tropical Medicine and Hygiene, 79(1), pp.63-6. Available at: http://www.ncbi.nlm.nih.gov/pubmed/2859676 [Accessed September 3, 2017].

World Health Organization, 2017. Dengue vaccine: WHO position paper, July 2016 recommendations. Vaccine, 35(9), pp.1200-1201. Available at: http://linkinghub.elsevier.com/retrieve/pii/S0264410X16310192 [Accessed November 11, 2017].

World Health Organization (WHO), 2012. Hand Boolk for Clinical Management of Dengue. Available at: http://www.who.int/about/licensing/copyright_form/en/index.html [Accessed November 10, 2017].

Zaki, A. et al., 2008. Phylogeny of dengue viruses circulating in Jeddah, Saudi Arabia: 1994 to 2006. Tropical Medicine \& International Health, 13(4), pp.584-592. Available at: http://www.ncbi.nlm.nih.gov/pubmed/18248565 [Accessed September 4, 2017].

Zaki, A.M., 1997. Isolation of a flavivirus related to the tick-borne encephalitis complex from human cases in Saudi Arabia. Transactions of the Royal Society of Tropical Medicine and Hygiene, 91(2), pp.179-81. Available at: http://www.ncbi.nlm.nih.gov/pubmed/9196762 [Accessed December 30, 2016]. 
Table 1: Aedes species according to the Region in Saudi Arabia

\begin{tabular}{|c|c|c|c|}
\hline Species & Region & Year & Reference \\
\hline $\begin{array}{l}\text { Aedes aegypti, Aedes } \\
\text { arabiensis and Aedes } \\
\text { caspius. }\end{array}$ & Western & 1956 & (Alikhan et al. 2014) \\
\hline Aedes caspius & Eastern & 1985 & (Wills et al. 1985) \\
\hline Aedes caspius & South western & 1995 & $\begin{array}{l}\text { (Abdullah \& Merdan } \\
\text { 1995) }\end{array}$ \\
\hline Aedes vittatus & Southern & 2001 & (Alikhan et al. 2014) \\
\hline $\begin{array}{l}\text { Aedes } \\
\text { arabiensis, } \\
\text { vittatus, } \\
\text { caspius and Aedes } \\
\text { caballus }\end{array}$ & Jizan & 2002 & (Jupp et al. 2002) \\
\hline $\begin{array}{l}\text { Aedes } \\
\text { caspius and Aedes } \\
\text { aegypti }\end{array}$ & Jeddah & 2011 & $\begin{array}{l}\text { (Al Ahmad et al. } \\
\text { 2011) }\end{array}$ \\
\hline $\begin{array}{l}\text { Aedes aegypti, Aedes } \\
\text { (Ochlerotatus) } \\
\text { caspius, Aedes } \\
\text { (Ochlerotatus) } \\
\text { vexans var. arabiensis }\end{array}$ & Jeddah & 2014 & (Alikhan et al. 2014) \\
\hline
\end{tabular}




\begin{tabular}{|l|l|l|l|}
\hline $\begin{array}{l}\text { Aedes caspius, } \\
\text { A. aegypti and others }\end{array}$ & Makkah & 2004-2006 & (Alahmed et al. 2009) \\
\hline Aedes caspius, & Madinah & 2010 & (Kheir et al. 2010) \\
A. aegypti and others & & & (Aziz et al. 2012) \\
\hline $\begin{array}{l}\text { co-breeding of Aedes, } \\
\text { Culex and Anopheles }\end{array}$ & Makkah & $2008-2009$ & \\
\hline
\end{tabular}


Table 2: A Summary of the incidence of Dengue virus infection among tested patients based on the location, year of the study and the method of testing

\begin{tabular}{|c|c|c|c|c|c|}
\hline Study type & $\begin{array}{l}\text { Study } \\
\text { population }\end{array}$ & $\begin{array}{l}\text { Method of } \\
\text { detection }\end{array}$ & $\begin{array}{l}\text { Number } \\
\text { included }\end{array}$ & \% positive & Reference \\
\hline Cross sectional & $\begin{array}{l}\text { Male blood } \\
\text { donors }\end{array}$ & ELISA & 910 & $39 \mathrm{IgG} ; 5.5 \mathrm{IgM}$ & $\begin{array}{l}\text { (Ashshi 2017; } \\
\text { Ashshi et al. } \\
\text { 2017) }\end{array}$ \\
\hline Longitudinal & Suspected cases & Viral culture & 985 & 21 & $\begin{array}{l}\text { (Fakeeh \& Zaki } \\
\text { 2001) }\end{array}$ \\
\hline Longitudinal & Suspected cases & ELISA & 985 & 11 & $\begin{array}{l}\text { (Fakeeh \& Zaki } \\
\text { 2001) }\end{array}$ \\
\hline Cross sectional & $\begin{array}{l}\text { random sample } \\
\text { of patients } \\
\text { attending the } \\
\text { outpatients' }\end{array}$ & ELISA & 965 & $31.7 \mathrm{IgG}$ & $\begin{array}{l}\text { (Al-Azraqi et al. } \\
\text { 2013) }\end{array}$ \\
\hline
\end{tabular}




\begin{tabular}{|c|c|c|c|c|c|}
\hline & $\begin{array}{l}\text { clinics in Jizan } \\
\text { and Aseer region }\end{array}$ & & & & \\
\hline $\begin{array}{l}\text { Longitudinal } \\
\text { April to July } \\
2004\end{array}$ & $\begin{array}{l}\text { clinically } \\
\text { suspected } \\
\text { patients, Makkah }\end{array}$ & $\begin{array}{l}\text { ELISA and RT- } \\
\text { PCR }\end{array}$ & 160 & $\begin{array}{l}40 \quad(n=64) \text { IgM } \\
\text { ELISA, } \\
(n=14) \text { by RT- } \\
\text { PCR and } 8.1(n \\
=13) \text { by both }\end{array}$ & $\begin{array}{l}\text { (Khan et al. } \\
\text { 2008) }\end{array}$ \\
\hline $\begin{array}{l}\text { Longitudinal } \\
\text { May 2004- April } \\
2005\end{array}$ & $\begin{array}{l}\text { clinically } \\
\text { suspected } \\
\text { patients, Jeddah }\end{array}$ & ELISA & 80 & 48.7 & $\begin{array}{l}\text { (Ayyub et al. } \\
\text { 2006) }\end{array}$ \\
\hline NA & $\begin{array}{l}\text { clinically } \\
\text { suspected } \\
\text { patients, Makkah }\end{array}$ & RT-PCR & 25 & 24 & $\begin{array}{l}\text { (Organji et al. } \\
\text { 2017) }\end{array}$ \\
\hline $\begin{array}{l}\text { Longitudinal } \\
2006 \text { to } 2008\end{array}$ & $\begin{array}{l}\text { clinically } \\
\text { suspected } \\
\text { patients, Makkah }\end{array}$ & $\begin{array}{l}\text { ELISA or RT- } \\
\text { PCR }\end{array}$ & 159 & 100 & $\begin{array}{l}\text { (Shahin et al. } \\
\text { 2009) }\end{array}$ \\
\hline
\end{tabular}




\begin{tabular}{|c|c|c|c|c|c|}
\hline $\begin{array}{l}\text { Longitudinal } \\
1994 \text { to } 2002\end{array}$ & $\begin{array}{l}\text { clinically } \\
\text { suspected } \\
\text { patients, Jeddah }\end{array}$ & $\begin{array}{l}\text { Virus isolation } \\
\text { or ELISA }\end{array}$ & 1020 & $\begin{array}{l}31.3 \text { of those } \\
65.5 \% \text { by virus } \\
\text { isolation and the } \\
\text { rest were based } \\
\text { on serology) }\end{array}$ & $\begin{array}{l}\text { (Fakeeh \& Zaki } \\
\text { 2003) }\end{array}$ \\
\hline $\begin{array}{l}\text { September to } \\
\text { mid December } \\
\text { in } 2006\end{array}$ & $\begin{array}{l}\text { Admitted } \\
\text { patients, Makkah }\end{array}$ & $\begin{array}{l}\text { Virus isolation } \\
\text { or ELISA }\end{array}$ & 71 & 100 & $\begin{array}{l}\text { (El-Gilany et al. } \\
2010)\end{array}$ \\
\hline $\begin{array}{l}\text { Longitudinal } \\
\text { study 2008- } \\
\text { 2012, Makkah }\end{array}$ & Confirmed cases & NA & 4187 & 100 & $\begin{array}{lll}\text { (alwafi et al. } & \\
\text { 2013) } & & \end{array}$ \\
\hline $\begin{array}{lr}\text { Cross } & \text { sectional } \\
\text { April } & 2010- \\
\text { March } & 2011, \\
& \\
\text { Jazan } & \\
\end{array}$ & Suspected cases & ELISA & 553 & 47.7 & $\begin{array}{lll}\text { (Gamil et al. } & \\
2014) & & \end{array}$ \\
\hline Cross sectional, & Seroprevalence & ELISA & 1024 & 0.1 & (Memish et al. \\
\hline
\end{tabular}




\begin{tabular}{|l|l|l|l|l|l|}
\hline 2009, Saudi & & & & & $2011)$ \\
military forces, & & & & & \\
Jazan & & & & & \\
\hline
\end{tabular}


Table 3: Summary of Characteristics of Confirmed Dengue Fever Cases in Saudi Arabia

\begin{tabular}{|c|c|c|c|c|c|c|}
\hline Number & $\begin{array}{l}\text { Study } \\
\text { population }\end{array}$ & $\begin{array}{l}\text { Method } \\
\text { of } \\
\text { detection }\end{array}$ & Serotype & Age & $\begin{array}{ll}\text { Male to } \\
\text { Female } \\
\text { ratio }\end{array}$ & Reference \\
\hline 91 & $\begin{array}{l}\text { clinically } \\
\text { suspected } \\
\text { patients, } \\
\text { Makkah }\end{array}$ & $\begin{array}{l}\text { ELISA } \\
\text { and RT- } \\
\text { PCR }\end{array}$ & $\begin{array}{ll}\text { DENV-2: } & 19 \\
(20.8 \%) & \\
\text { DENV-3: } & 4 \\
(4.3 \%) & \end{array}$ & $\begin{array}{l}\text { median } \\
\text { age: } 26 \\
\text { (range=6- } \\
94 \text { ) }\end{array}$ & $1.5: 1$ & $\begin{array}{l}\text { (Khan et al. } \\
\text { 2008) }\end{array}$ \\
\hline 39 & $\begin{array}{l}\text { clinically } \\
\text { suspected } \\
\text { patients, } \\
\text { Jeddah }\end{array}$ & ELISA & & $\begin{array}{l}\text { Range: } 2 \text { - } \\
60 ; \text { mean } \\
27.6 \pm \\
11.2\end{array}$ & $3.3 .: 1$ & $\begin{array}{l}\text { (Ayyub et al. } \\
2006 \text { ) }\end{array}$ \\
\hline 25 & $\begin{array}{l}\text { clinically } \\
\text { suspected } \\
\text { patients, } \\
\text { Makkah }\end{array}$ & RT-PCR & $\begin{array}{l}\text { DENV-1 } \\
50 \% \quad \text { DENV- } \\
2 \quad 33.3 \% \\
\text { DENV-3: } \\
16.6 \%\end{array}$ & & & $\begin{array}{l}\text { (Organji et } \\
\text { al. 2017) }\end{array}$ \\
\hline 159 & $\begin{array}{l}\text { clinically } \\
\text { suspected } \\
\text { patients, } \\
\text { Makkah }\end{array}$ & $\begin{array}{l}\text { ELISA or } \\
\text { RT-PCR }\end{array}$ & & $\begin{array}{l}25.6 \pm 16.1 \\
\text { years } \\
\text { (range } 4 \\
\text { to } 81 \\
\text { years) }\end{array}$ & $2: 1$ & $\begin{array}{l}\text { (Shahin et al. } \\
\text { 2009) }\end{array}$ \\
\hline
\end{tabular}




\begin{tabular}{|c|c|c|c|c|c|c|}
\hline 319 & $\begin{array}{l}\text { clinically } \\
\text { suspected } \\
\text { patients, } \\
\text { Jeddah }\end{array}$ & $\begin{array}{l}\text { Virus } \\
\text { culture or } \\
\text { serology }\end{array}$ & $\begin{array}{l}\text { DENV-1: } \\
27 \% \\
\text { DENV-2: } \\
66 \% \\
\text { DENV-2: } 6 \%\end{array}$ & $\begin{array}{l}\text { adults } \\
\text { between } \\
15-40 \\
\text { years }\end{array}$ & $2.6: 1$ & $\begin{array}{l}\text { (Fakeeh \& } \\
\text { Zaki 2003) }\end{array}$ \\
\hline 71 & $\begin{array}{l}\text { admitted to } \\
\text { hospitals in } \\
\text { Holly } \\
\text { Makkah } \\
\text { City, } 2006 \\
\text { (during the } \\
\text { Hajj) }\end{array}$ & $\begin{array}{l}\text { Virus } \\
\text { culture or } \\
\text { serology }\end{array}$ & & $\begin{array}{l}\text { Adults } \\
16-44 \\
\text { years }\end{array}$ & $1.7: 1$ & $\begin{array}{l}\text { (El-Gilany et } \\
\text { al. 2010) }\end{array}$ \\
\hline 4187 & $\begin{array}{l}\text { Confirmed } \\
\text { cases } \\
\text { reported to } \\
\text { the Ministry } \\
\text { of Health }\end{array}$ & NA & NA & $\begin{array}{l}47 \% \\
\text { between } \\
25 \text { and } 44 \\
\text { years }\end{array}$ & 2.6:1 & $\begin{array}{l}\text { (alwafi et al. } \\
\text { 2013) }\end{array}$ \\
\hline 264 & $\begin{array}{l}\text { Confirmed } \\
\text { cases, Jazan }\end{array}$ & ELISA & NA & $\begin{array}{l}52 \% \\
\text { between } \\
15 \text { and } 44 \\
\text { years }\end{array}$ & & $\begin{array}{l}\text { (Gamil et al. } \\
\text { 2014) }\end{array}$ \\
\hline 19 & $\begin{array}{l}\text { Isolates in } \\
\text { Jeddah }\end{array}$ & RT-PCR & $\begin{array}{l}\text { DENV-1, } \\
\text { DENV-2 and }\end{array}$ & & & $\begin{array}{l}\text { (Zaki et al. } \\
\text { 2008) }\end{array}$ \\
\hline
\end{tabular}




\begin{tabular}{|l|l|l|l|l|l|l|}
\hline 567 & Cross & RT-PCR & Not reported & $85 \%$ were & $2: 1$ & \\
\hline & $\begin{array}{l}\text { sectional of } \\
\text { confirmed } \\
\text { cases }\end{array}$ & & & adults & & et al. 2017) \\
& & & & & & \\
\hline
\end{tabular}


Table 4: Signs and Symptoms of Patients with Dengue Fever, Numbers are percentage unless indicated otherwise

\begin{tabular}{|c|c|c|c|c|}
\hline & $\begin{array}{l}\text { (Khan et } \\
\text { al. 2008) }\end{array}$ & $\begin{array}{l}\text { (Ayyub } \\
\text { et al. } \\
\text { 2006) }\end{array}$ & $\begin{array}{l}\text { (Shahin } \\
\text { et al. } \\
\text { 2009) }\end{array}$ & $\begin{array}{l}\text { (El- } \\
\text { Gilany } \\
\text { et al. } \\
2010)\end{array}$ \\
\hline $\begin{array}{l}\text { Total number } \\
\text { of patients }\end{array}$ & 91 & 39 & 159 & 71 \\
\hline Fever & 100 & 100 & 100 & 100 \\
\hline Malaise & 83 & 66.7 & & 67 \\
\hline Musculoskeletal & 81 & & 100 & 59 \\
\hline Headache & 75 & 48.7 & 100 & 74 \\
\hline Nausea & 69 & 25.6 & 27 & 42.3 \\
\hline Vomiting & 65 & & 27 & 39.4 \\
\hline Abdominal pain & 48 & & 24.5 & 39.4 \\
\hline Dengue fever & 93 & & 90 & 60.5 \\
\hline DHF & 7 & 5 & 10 & 39.4 \\
\hline DSS & 1 & & 0.6 & \\
\hline Mortality & & 0 & 0.6 & 1.4 \\
\hline
\end{tabular}


Figure 1: Genus Flavivirus and the Dengue Virus

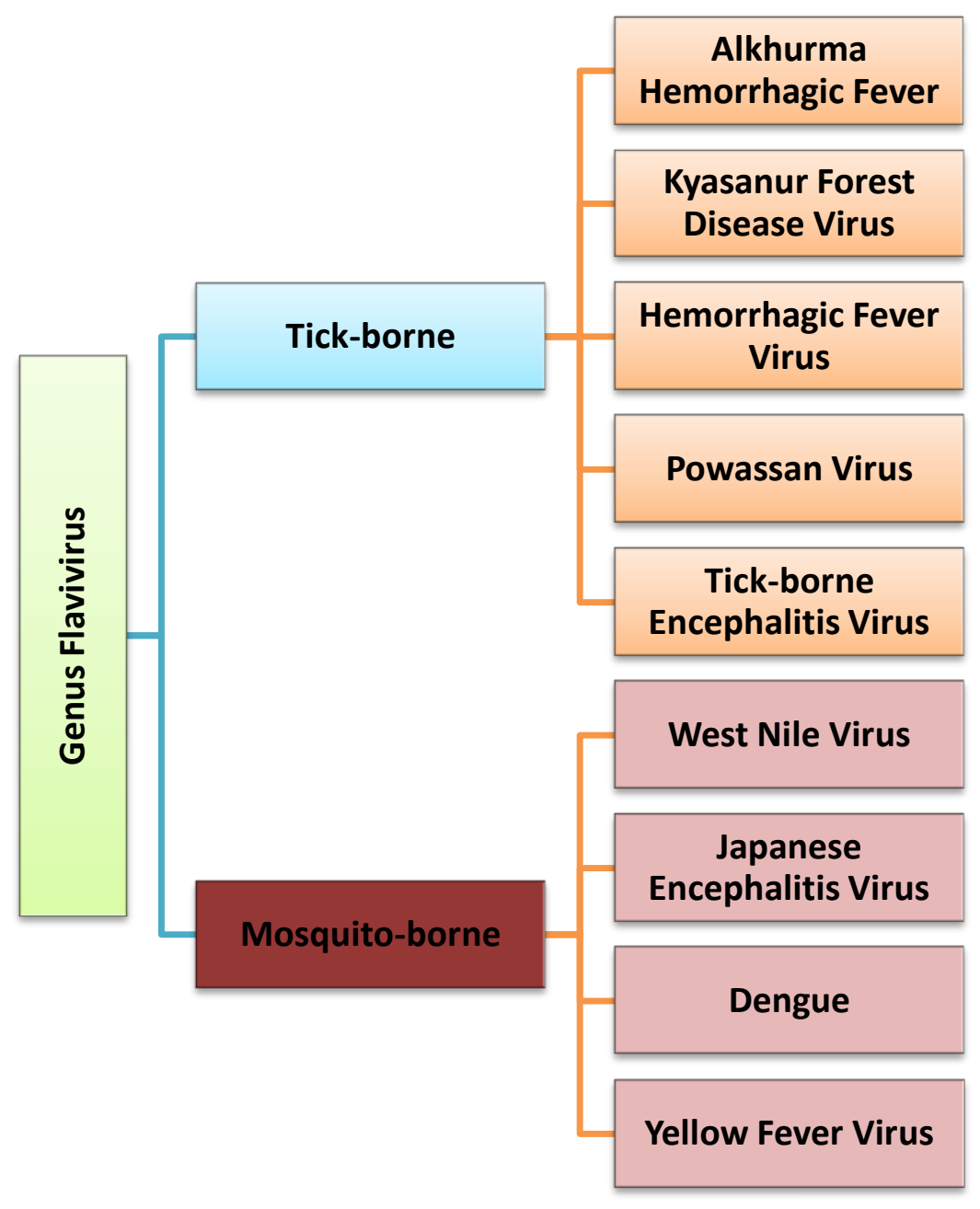


Figure 2: Annual Number of Dengue Fever Cases in Saudi Arabia, Data from (Alshamrani et al. n.d.; Organji et al. 2017; Saudi Ministry of Health n.d.)

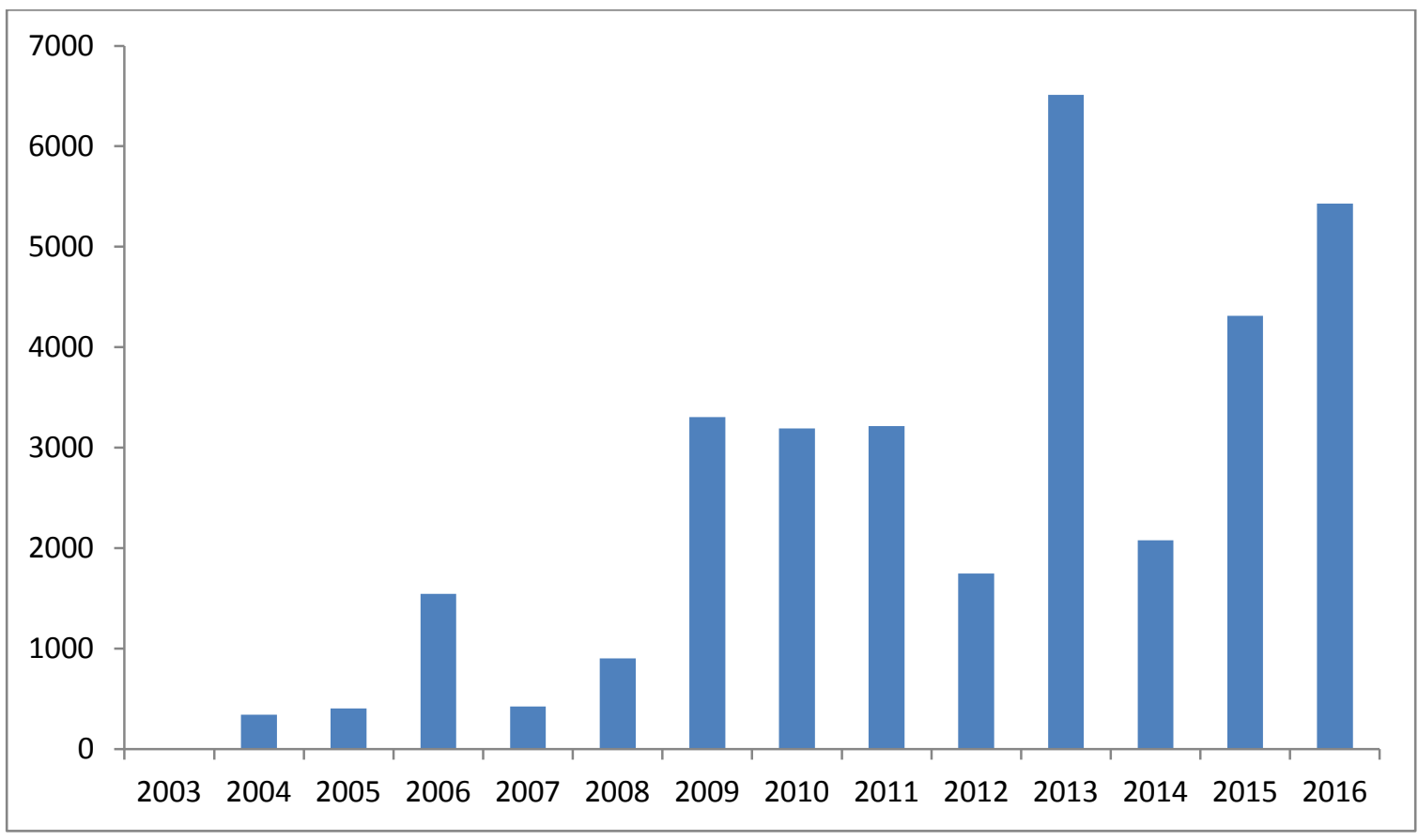

